\title{
Technical Adequacy of the Student Protective Factors Screening Scale (SPF-7) as a Universal Screening Tool
}

\author{
Julie Q. Morrison \\ University of Cincinnati, School Psychology Program, Cincinnati, USA \\ Email: Julie.Morrison@uc.edu \\ Received 7 April 2015; accepted 30 May 2015; published 2 June 2015 \\ Copyright @ 2015 by author and Scientific Research Publishing Inc. \\ This work is licensed under the Creative Commons Attribution International License (CC BY). \\ http://creativecommons.org/licenses/by/4.0/ \\ (c) (i) Open Access
}

\begin{abstract}
Universal screening is a critical foundation for school-based prevention and early intervention. This study examined the technical adequacy of the SPF-7, an instrument designed to assist school personnel in the early identification of students at-risk for emotional and behavioral concerns. The SPF-7 differs from other measures used in identifying emotionally and behaviorally at-risk students, as the SPF-7 focuses on protective factors rather than risk factors. The results of this study suggest that the SPF-7 has adequate test-retest reliability and criterion validity, but limited inter-rater agreement. The SPF-7 is a potentially promising tool for identifying students in need of support within a multi-tiered system of increasingly intensive interventions.
\end{abstract}

\section{Keywords}

\section{Universal Screening, Protective Factors}

\section{Introduction}

The early detection of factors that place children at risk for emotional and behavioral challenges is crucial to the prevention of more serious difficulties later in their development. Just as the medical community employs universal screening for the detection and early treatment of cancers originating in the breast, colon, cervix, and prostate, universal screening for emotional and behavioral difficulties in children can reduce the need for more intensive, expensive, and potentially less successful treatment later in a child's school career (Kaplan, 2000; Kazdin, 1987; Lane, Menzies, Oakes, Kalberg, 2012; Severson, Walker, Hope-Doolittle, Kratochwill, \& Gresham, 2007). Although it is clear that intervention provided at younger ages has a greater likelihood of success, the key to that success relies in large part on the availability of a reliable method for identifying children in need 
of services (Elliott, Huai, \& Roach, 2007; Severson et al., 2007). Lacking a reliable, proactive method for recognizing students in need, far too often, schools respond in a reactive manner, waiting for students to exhibit difficulties in behavior before taking action to intervene (Gresham, 2004; Walker \& Shinn, 2002).

\subsection{A Primary Prevention Approach}

The United States Public Health Service describes three levels of "prevention" outcomes: primary prevention, secondary prevention, and tertiary prevention. In this three-tiered model, prevention is considered an outcome in and of itself, rather than simply a means to an end. Primary prevention seeks to prevent harm. Efforts by the medical community to promote wellness through good nutrition, exercise, and a balanced and healthy lifestyle represent the first line of defense in an effective public health program. Until recent advances in school-wide positive behavioral supports (e.g., Anderson \& Kincaid, 2005; Horner, Sugai, Todd, \& Lewis-Palmer, 2005; Osher, Dwyer, \& Jimerson, 2006; Sprague \& Horner, 2006; Sugai \& Horner, 2002) and response to intervention (Barnett, Daly, Jones, \& Lentz, 2004; Brown-Chidsey \& Steeg, 2005; Gresham, 2004, 2005; Marston, 2005), primary prevention efforts addressing social and emotional concerns in schools been limited. Instead, the focus has been on secondary prevention, which seeks to reverse harm, and tertiary prevention, which seeks to reduce harm amongst the most behaviorally-challenged students.

In recent years, the three-tiered prevention model has recast in terms of levels of interventions that differ in terms of the nature, comprehensiveness, and intensity (see Gresham, 2004). This model of intervention is composed of three levels of intervention intensity: universal interventions, selected interventions, and targeted/ intensive interventions (see Gresham, 2004). The three-tiered approach to intervention provides for the immediate assistance of students who are struggling with academic or behavioral concerns and emphasizes the proactive identification of students at risk. Despite advances in the development and use of universal screening methods for identifying children in need of academic interventions and measuring the outcomes of universal, selected, and targeted interventions, the use of assessment methods for the early identification of emotional and behavioral concerns in schools remains limited. Screening tools that are available and have demonstrable technical adequacy include the Behavioral and Emotional Screening System (BESS; Kamphaus \& Reynolds, 2007), the Social and Academic Behavior Risk Screener (SABRS; Kilgus, Chafouleas, \& Riley-Tillman, 2013), the Systematic Screening for Behavioral Disorders (SSBD; Todis, Severson, \& Walker, 1990), and the Student Archival Records Search (SARS; Walker, Block-Pegego, Todis, \& Severson, 1991). In addition, a number of studies support the use of review of office discipline referrals as a screening system for behavior problems (e.g., Irvin et al., 2006; Irvin, Tobin, Sprague, Sugai, \& Vincent, 2004; Putnam, Luiselli, Handler, \& Jefferson, 2003; Sugai, Sprague, Horner, \& Walker, 2001). All of these screening tools select students based on the presence of established behavioral concerns, rather than assessing students proactively based on their competencies.

\subsection{The Use of Local Norms for Universal Screening}

A local norm is a description of a population's performance on a set of tasks, developed to represent students from a particular school or school system (Habedank, 1995). As such, they provide direct measures of a student's performance in a given instructional context relative to peers within that same ecology. The rationale for developing local norms relies on the recognition that students interact within a unique, contextually-specific ecology, and this context provides an opportunity to make normative comparisons that are unique and contextually sensitive (Gresham, 2004). As such, the use of local norms is wholly consistent with a three-tiered model of intervention, where universal interventions are provided in a manner that is situation-specific and contextually sensitive to the needs of the students in that local classroom or school environment (Ikeda, Neessen, \& Witt, 2008).

Experts in measurement have long recognized the benefits of local norms. Local norms are judged to be more appropriate than broad national norms for many testing purposes, such as the prediction of subsequent job performance or college achievement, the comparison of a child's relative achievement in different subjects, or the measurement of an individual's progress over time (Anastasi, 1988). In addition, locally-normed assessments address many of the criticisms of traditional norm-referenced assessments, namely that they are culturally and ethnically biased and function primarily to identify, classify, and sort students. Whereas, nationally-normed assessment measures frequently result in the overrepresentation of culturally, ethnically, and linguistically diverse students attaining "at-risk" status, local norms reflect what is relevant for success within the local context (Can- 
ter, Lau, \& House, 2002).

\subsection{Universal Screening with Protective Factors}

The Student Protective Factors Screening Scale (SPF-7) investigated in this study employs the same matrix system used by the Student Risk Screening Scale (SRSS, Drummond, 1993). On the SRSS, first column of the matrix is used to list students' names. Seven behavioral descriptors appear across the top of the rating form: a) stealing; b) lying, cheating, sneaking; c) behavior problems; d) peer rejection; e) low academic achievement, f) negative attitude; and g) aggressive behavior. The classroom teacher compares each student against all others in the classroom as they rate each behavioral descriptor. Every student is assigned a rating, ranging from $0=$ "Never" to 3 = "Frequently," for each of the seven descriptors. The SRSS is considered brief, research-based, easily understood, cost efficient, and valid for use in universal screening (Feil, Severson, \& Walker, 2002; Lane, Kalberg, Parks, \& Carter, 2008; Walker, Colvin, \& Ramsey, 1995).

Unlike the SRSS, however, which gathers a teacher's ratings on seven behavioral risk factors (e.g., stealing, negative attitude, aggressive behavior), the SPF-7 involves teacher ratings of individual students on seven protective factors identified by a preponderance of the empirical research on social/behavioral competence and resiliency as strong correlates of positive developmental outcomes: a) demonstrates competence, is optimistic, and has a sense of purpose; b) has effective social skills; relates well to others, has good friendship skills, c) shows respect and concern for others; empathy, d) identifies with a pro-social peer group, e) engaged and motivated to do well in school; f) connected with teachers and school, and g) family is supportive and invested in student's school success. Within the context of a response to intervention model, the SPF-7 could be used to identify specific skills to target for more intensive intervention (e.g., specific social skills interventions, Check In/Check Out: school-wide positive behavioral support).

\subsection{Relationships among Protective Factors and Positive Child Outcomes}

Protective factors are antecedent conditions associated with a decrease in the likelihood of undesirable outcomes, or an increase in the likelihood of positive outcomes (Kazdin, Kraemer, Kessler, \& Kupfer, 1997). In this section, the empirical basis for each of the protective factors used by the SPF-7 will be reviewed.

Competence. Competence refers to a pattern of effective adaption in the environment, either broadly defined in terms of success with the major developmental tasks expected for a child of a given age in the context of his or her culture, or more narrowly defined with respect to achievement in specific domains, such as academics, peer acceptance, or athletics (Masten \& Coatsworth, 1998). According to Masten and Coatsworth (1998), competence "carries the dual meaning that there is a track record of such achievement (competent performance) and also that the individual has the capability to perform well in the future. It refers to good adaptation and not necessarily to superb achievement" (p. 206). Competence results from complex interactions between a child and his or her environment. As such, a student's competence (and a teacher's assessment of that student's competence) will change as the child develops and changes or when the context changes.

Academic achievement, conduct (how well one follows the rules), and getting along with other children (social competence) are the three key components of competence for school-age children (Masten \& Coatsworth, 1998). DiPerna and Elliott (2000) defined academic competence as "a multidimensional construct composed of the skills, attitudes, and behaviors of a learner that contribute to academic success in the classroom” (p. 1). Social competence is defined as the ability to recruit social networks, to meet the demands of teachers, (who control the classrooms) and peers (who control the playgrounds), and to adapt to changing conditions in one's environment (Walker et al., 1983). Social competence, and competence in general, are evaluative terms based on judgments that a student has performed competently on a task put forth by significant others (e.g., teachers, parents, peers), comparisons to explicit criteria (e.g., number of tasks correctly performed), and/or comparisons to a normative sample (Gresham, 2002).

The degree to which children and youth exhibit skills characteristic of social competence predicts adequate long-term psychological and social adjustment (Kupersmidt, Coie, \& Dodge, 1990; Parker \& Asher, 1987). Social competence is associated with a history of lower stress reactivity and higher self-control of attention and behavior (Eisenberg et al., 1997), such that deficits in social competence have been implicated in the development of several childhood disorders characterized by an externalizing behavior pattern such as oppositional defiant disorder, conduct disorder, and attention deficit/hyperactivity disorder (Achenbach, 1985; Hinshaw, 1987; 
Kazdin, 1987).

Social Skills. Social skills are specific behaviors that a student exhibits to perform competently on a social task such as making requests, starting a conversation, or giving a compliment (Gresham, 2002). The acquisition and fluent use of specific social skills leads to an overall judgment of social competence, but these terms are not interchangeable (Walker, Colvin, \& Ramsey, 1995). According to Gresham (2002), “social skills are behaviors that must be taught, learned, and performed, whereas social competence represents judgments or evaluations of those behaviors within and across situations over time" (p. 1030).

The development of a repertoire of social skills is related to positive short-term and long term outcomes for students (Caprara, Barbaranelli, Pastorelli, Bandura, \& Zimbardo, 2000). Social skills have been found to be a significant predictor of academic competence, and academic competence, in turn, was a significant predictor of achievement (Malecki \& Elliott, 2002). In a longitudinal study investigating protective factors of inner city youth, youth with effective social skills were found to have lower rates of depression (Smokowski, Mann, Reynolds, \& Fraser, 2004). Likewise, the relationship between effective social skills and lower rates of externalizing and internalizing behavior problems in youth has been demonstrated consistently in numerous studies (e.g., Alvord \& Grados, 2005; Criss, Pettit, Bates, Dodge, \& Lapp, 2002; Steinhausen \& Metzke, 2001). Students who have not demonstrated the use of appropriate social skills by about third grade are likely to continue to display some degree of antisocial behavior (Kazdin, 1987; Patterson, DeBaryshe, \& Ramsey, 1989) and co-occuring learning disabilities (Hinshaw, 1992; Kavale \& Forness, 1998) throughout their lives.

Show Respect or Concern for Others (Empathy). Empathy is the understanding of and sharing in, another's emotional state. Children who are empathetic are a) capable of experiencing another person's emotions vicariously and b) able to understand the feelings that person is experiencing (de Wied, Goudena, \& Matthys, 2005). The capacity to demonstrate empathy is associated with a decreased likelihood for exhibiting externalizing behavior problems. Among a sample of boys aged 8 - 12, those with high levels of aggressive and disruptive behaviors were less likely to demonstrate empathy, whereas boys with low levels of aggressive and disruptive behavior demonstrated a greater capacity to be empathetic (de Wied et al., 2005). Strong links have been found between empathy and prosocial behavior when these constructs were assessed across methods and sources (laboratory tasks and ratings from parents, children, best friends, and teachers) for school-age children (Roberts \& Strayer, 1996). Empathy was associated with direct observations of anger and aggression in peer play groups among five-year-old children (Strayer \& Roberts, 2004).

Identifies with Pro-Social Peers. It is not enough for a student to demonstrate skills necessary to make friends. Current research suggests that having the right kind of friends is critically important to successful developmental outcomes for students. Children who succeed in school are more likely to adopt and comply with social norms and identify with prosocial peer groups (Catalano \& Hawkins, 1996). Conversely, in other peer social contexts aggressive behavior is expected and reinforced (Coie \& Jacobs, 1993). Prosocial children tend to choose peers who have prosocial influences and aggressive children tend to choose peers who exacerbate their negative behavior (Masten \& Coatsworth, 1998). Not surprisingly, research suggests negative child outcomes are more prevalent among children who have fewer mutual friends, are victimized by peers, or are rejected by classmates (Kochenderfer \& Ladd, 1996; Kupersmidt \& Coie, 1990; Ladd, Kochenderfer, \& Coleman, 1997). Peers may also influence academic achievement either positively or negatively (Epstein, 1983), and for some students, the peer group may be a more powerful determinant of their school competence than their parents (Brown \& Huang, 1995; Steinberg, 1996). Affiliation with high-achieving peers can influence satisfaction with school, expectations, grades, and test scores (Epstein, 1983; Mounts \& Steinberg, 1995). In contrast, affiliation with antisocial peers can reinforce and intensify antisocial behavior (Bassarath, 2001; Cairns, Cairns, Neckerman, Gest, \& Gariepy, 1988; Dishion, Andrews, \& Crosby, 1995; Dishion, Patterson, Stoolmiller, \& Skinner, 1991; Spoth, Yoo, Kahn, \& Redmond, 1996).

Engaged and Motivated to Do Well in School. Although there is little consensus in the theoretical and research literatures regarding the definition of engagement and how it is operationalized and measured (Appleton, Christenson, \& Furlong, 2008; Fredericks, Blumenfeld, \& Paris, 2004; Furlong et al., 2003; Jimerson, Campos, \& Greif, 2003), there is consensus that student engagement is a multidimensional construct, that includes behavioral, affective, and cognitive dimensions (Finn, 1989; Fredericks et al., 2004; Jimerson et al., 2003). Behavioral engagement is characterized by positive conduct, attendance, active participation, and effort. Affective engagement reflects a sense of belonging, identification, interest, and a positive attitude about learning. Cognitive engagement refers to perceiving that school is relevant to future aspirations, investment in learning, and 
self-regulation. Some definitions of engagement include a fourth dimension, academic engagement, which reflects the amount of time a student spends engaged in learning (Reschly \& Christenson, 2006a, 2006b).

Engagement was identified by DiPerna, Volpe, and Elliott (2002) as a key “academic enabler" predictive of student achievement. In two large-scale studies, engagement (operationalized as participation) was associated with academic achievement among eighth students, such that a) identification with school was related to participation, and b) participation was related to achievement, and c) levels of participation predicted the variation in reading and math achievement of at-risk students (Finn, 1993). Similar findings were obtained among a sample of economically disadvantaged African American and Hispanic students in Grades 8 to 12 (Finn \& Rock, 1997). In addition to increases in academic achievement, engagement, defined as classroom participation, was found to be a strong predictor of decreases in antisocial behavior among a sample of fifth and sixth grade students (Morrison, Robertson, Laurie, \& Kelly, 2002).

A primary focus of the theoretical and research literatures on engagement has examined the relationship between engagement as an alterable variable to prevent dropout (Christenson et al., 2001; Connell, HalpernFelsher, Clifford, Crichlow, \& Usinger, 1995; Doll, Hess, \& Ochoa, 2001) and a potential target for intervention to promote student achievement (National Research Council \& Institute of Medicine, 2004).

Connected with Teachers and School. Connectedness reflects youths' activity with and affection for the people, places, and activities within their life (Baumeister \& Leary, 1995). Youth who feel a connection to school and their teachers experience a sense of belonging in their interactions with members of the school community. These youth typically have personal connections with one or more teachers who serve as mentors during their school years and beyond.

A caring relationship with one or more adults has been cited as a powerful protective factor for children at risk for a variety of problematic social behaviors, including substance abuse and school dropout (Doll \& Lyon, 1998). Studies have shown a positive association between the quality of student-teacher relationships and variables contributing to school success, such as academic motivation, engagement, and attitudes toward school (Anderman \& Maehr, 1994; Birch \& Ladd, 1997; Eccles et al., 1993; Henricsson \& Rydell, 2004; Murray \& Greenberg, 2000; Pianta, Steinberg, \& Rollins, 1995). Conversely, low connectedness to school predicts adolescent depression, risk taking, underachievement, and alienation from peers, teachers, and parents (Bonny, Britto, Klostermann, Hornung, \& Slap, 2000; Karcher, 2002; Karcher, Davis, \& Powell 2002; Kuperminc, Blatt, \& Leadbeater, 1997).

Family is Supportive and Invested in Student's School Success. Family involvement in a student's education in any form can be a powerful predictor of school success. Family members have a positive effect on achievement through their attitudes and behavior, for example, by communicating strong educational values (Majoribanks, 1987), conveying the value of effort (Stevenson, Chen, \& Lee, 1993), expecting and encouraging their child to succeed academically (Reynolds \& Wahlberg, 1991), and monitoring or helping with their child's schoolwork at home (Clark, 1993; Scott-Jones, 1995).

Ample evidence is available to suggest that parental involvement in education is related to a child's academic achievement (Booth \& Dunn, 1996; Ryan, Adams, Gullotta, Weissberg, \& Hampton, 1995) and short-term longitudinal evidence indicates that increasing parental involvement leads to academic improvements (Steinberg, Lamborn, Dornbusch, \& Darling, 1992). More generally, students who perceive their family as more supportive experience lower rates of maladaptive behaviors (Dunn \& Tucker, 1993; Piko, Fitzpatrick, \& Wright, 2005), whereas students with low family support have higher risk of suicide (Morano, Cisler, \& Lemerond, 1993), depressive symptoms and conduct problems (Garnefski \& Diekstra, 1996).

\subsection{Purpose of the Current Study}

The purpose of this study is to investigate the reliability and validity of a universal screening instrument developed by the authors that can be used to create local behavioral norms based on protective factors. The Student Protective Factors Screening Scale (SPF-7) employs the same matrix system used by the SRSS. Unlike the SRSS, however, which gathers a teacher's ratings on seven behavioral risk factors (e.g., stealing, negative attitude, aggressive behavior), the SPF-7 involves teacher ratings of individual students on seven protective factors (See Appendix). These protective factors were selected for the screening scale for two reasons. First, they have been identified by empirical research as strong correlates of positive developmental outcomes. Second, these protective factors are readily observable and measurable by teachers within the school context. The SPF-7 represents a positive, prevention approach to the early detection and intervention of behavioral and emotional 
concerns. Used within a response to intervention model, the SPF-7 has the potential utility of other instruments validated for use in universal screening: a) administered to an entire class/grade/school/district using either individual or group format; b) an indicator that there is a potential problem in need of further investigation; c) an answer to the question: Which and how many students are potentially in need of additional support? d) quantitative; e) one piece of information required to determine additional needs; f) cost effective in terms of teacher time, student time, and dollar cost for testing and scoring; g) relevant for pre-K-12 grades; h) a sampling of one point in time; i) a sample of a skill; j) capable of identifying students who exceed or fall below the expectations/ standards, k) results in an action or decision: information must be used, l) easily administered, scored, and interpreted, $\mathrm{m}$ ) used proactively. Teachers typically spent about one minute per student when assessing a class using the SPF-7, a process that would be completed at three benchmark periods (i.e., Fall, Winter, Spring) during the school year.

\section{Method}

\subsection{Participants}

The participants in this study were 84 teachers serving students in Grades K-8 who were asked by their building school psychologist to provide ratings of the students in their classes. Fifty-nine teachers served students in urban, public elementary schools, 21 teachers served students in urban, Catholic elementary schools, and 4 teachers served children in suburban, public schools. Among the participating teachers, 75 (89.3\%) were female and 7 (8.3\%) were male. Two teachers did not provide information about their gender. Sixty-four (76.2\%) of the participating teachers identified their race as White, 14 (16.7\%) as African American, 2 (2.4\%) and Hispanic, and 2 (2.24\%) as Multi-Racial. Two teachers did not provide information about their race. The mean number of years of teaching experience (self-reported) was 15.2, with a range of 0 - 35 years.

\subsection{Sample}

The sample of students for whom teacher ratings were provided was comprised of 1,594 students. There were 785 female students (49.2\%) and 805 male students (50.5\%). The gender of four students in the sample was not reported. The racial distribution of the sample was as follows: 801 (50.2\%) were African/African American, 619 (38.8\%) were White, 82 (5.1\%) were Multi-Racial, 54 (3.4\%) were Hispanic, and 30 (1.9\%) were Asian/Pacific Islander. The race of eight students in the sample was not reported. There were $245(15.4 \%)$ students in the sample with an identified disability. Among these students with disabilities, 78 (4.9\%) had a Speech and Language Disability, 70 (4.4\%) had a Specific Learning Disability, 49 (3.1\%) had a Cognitive Disability, 13 (<0.1\%) had an Other Health Impairment, $12(<0.1 \%)$ had an Emotional Disturbance classification, $8(<0.1 \%)$ were classified as having a Multiple Disability, $7(<0.1 \%)$ had Autism, $2(<0.1 \%)$ had a classification of Preschool Disability, and $1(<0.1 \%)$ student had each of the following disabilities: Traumatic Brain Injury and Visual Impairment. The disability classification was not reported for four students flagged as having an educational disability.

\subsection{Instrument}

The Student Protective Factors Screening Scale (SPF-7) was comprised of a matrix with students' names for an entire class listed in the first column and individual ratings on the seven behavioral descriptors to be provided by the teacher under each heading in the next seven columns (see Appendix). Across the top of the rating form, the headings for each column included seven protective factors identified by a preponderance of the empirical research on social/behavioral competence and resiliency as strong correlates of positive developmental outcomes: a) demonstrates competence, is optimistic, and has a sense of purpose, b) has effective social skills; relates well to others, has good friendship skills, c) shows respect and concern for others; empathy, d) identifies with a prosocial peer group, e) engaged and motivated to do well in school; f) connected with teachers and school, and g) family is supportive and invested in student's school success. As presented by the school's school psychologist, the classroom teacher was asked to compares each student against all others in the classroom as they rate each behavioral descriptor using the following scale: $0=$ Never, $1=$ Rarely, $2=$ Occasionally, $3=$ Frequently. In this study, the SPF-7 was presented as a paper-pencil measure, although it would lend itself to electronic administration in future studies and in practice. Teachers typically spent about one minute per student when assessing a class using the SPF-7, a process that would be completed at three benchmark periods (i.e., Fall, Winter, Spring) 
during the school year.

\subsection{Design and Procedures}

In this study, school psychologists gathered teachers' individual ratings for each student in their class with respects to seven protective factors on the SPF-7. The teachers supplied demographic information for themselves and the students in their class. Technical adequacy (i.e., test-retest reliability, inter-rater agreement, and criterion validity) was determined in the following fashion:

Test-retest reliability. Nine classroom teachers from eight different schools provided individual ratings of 138 students on the SPF-7 on two occasions spanning a 2-week period. Collectively, the teachers had an average of 14 years of teaching experience, with their years of teaching experience ranging from 3 - 32 years. Three classroom teachers from two schools provided individual ratings of 84 students on the SPF-7 on two occasions spanning an 18-week period. Collectively, the teachers had an average of 13 years of teaching experience, with their years of teaching experience ranging from 5 - 30 years.

Inter-rater agreement. Six homeroom teachers from two schools provided individual ratings of 89 students. A second teacher, judged by the principal to be familiar with the students in the class, provided independent ratings for each of the students in this subsample.

Criterion validity. Three teachers from two schools provided individual ratings of 91 students on the SPF-7. These ratings were compared with the students' overall school status as measured by the Student Archival Records Search (SARS). The SARS involves the systematic recording and quantification of archival school records using 11 archival variables (e.g., disciplinary referrals, negative narrative comments, within-school referrals, out-of-school referrals) (Walker et al., 1991). Research suggests that the SARS is a technically adequate instrument that can be used as a tool to identify students with behavioral and emotional concerns (Walker et al., 1991). School Psychology graduate students completed the SARS for each of the students in this subsample.

\subsection{Data Analyses}

This study employed correlational research methods to calculate the strength of the relationship between raters (inter-rater agreement), across measurement occasions (test-retest reliability), and in relation to the SARS (criterion validity). Pearson $r$ correlation coefficients were calculated to determine test-retest reliability, inter-rater reliability, and criterion validity. A multiple regression was used to determine the degree to which the seven protective factors, individually and collectively, predicted students' school status, as measured by the SARS (criterion variable). Descriptive statistics were used to summarize the teachers' ratings of the students on the SPF-7. The distribution of teacher ratings was examined by grade level and disability classification.

\section{Results}

\subsection{Test-Retest Reliability}

Pearson $r$ correlation coefficients were calculated to determine test-retest reliability (see Table 1). All seven protective factors were found to have adequate test-retest reliability across a 2-week timeframe, with coefficients ranging from $.84-.95$. All seven protective factors were found to have adequate test-retest reliability across an 18-week timeframe, with coefficients ranging from .76 - .93.

\subsection{Inter-Rater Agreement}

Pearson $r$ correlation coefficients were calculated to determine inter-rater reliability (see Table 2). None of the seven protective factors were found to have adequate inter-rater reliability, as determined by the following Pearson $r$ correlation coefficients: Competence (.42), Empathy (.55), Engaged (.57), and Family (.44), Social Skills (.25), Pro-social Peers (.22), Connected (.24). The results indicate that the independent judgments of classroom teachers are context-specific and do not agree necessarily with ratings provided by other educators outside of the classroom setting.

\subsection{Criterion Validity}

A multiple regression was used to determine the degree to which the seven protective factors, individually and 
Table 1. Test-retest reliability at 2 weeks and 18 weeks.

\begin{tabular}{ccc}
\hline Protective factor & 2 weeks & \multicolumn{1}{c}{18 weeks } \\
Competence & $.88^{* *}$ & 64 \\
Social skills & $.84^{* *}$ & $.88^{* *}$ \\
Empathy & $.88^{* *}$ & $.77^{* *}$ \\
Pro-social peers & $.95^{* *}$ & $.84^{* *}$ \\
Engaged & $.91^{* *}$ & $.78^{* *}$ \\
Connected & $.93^{* *}$ & $.83^{* *}$ \\
Family & $.91^{* *}$ & $.93^{* *}$ \\
\hline
\end{tabular}

${ }^{* *} p<0.01$.

Table 2. Inter-rater agreement for factors on the SPF-7 $(N=89)$.

\begin{tabular}{cccc}
\hline Protective factor & Same value & Within \pm one & Correlation coefficient \\
\hline Competence & $56.2 \%$ & $95.5 \%$ & $.42^{* *}$ \\
Social skills & $49.4 \%$ & $89.9 \%$ & $.25^{*}$ \\
Empathy & $49.4 \%$ & $98.9 \%$ & $.55^{* *}$ \\
Pro-social peers & $46.1 \%$ & $88.8 \%$ & $.22^{*}$ \\
Engaged & $57.3 \%$ & $97.8 \%$ & $.57^{* *}$ \\
Connected & $48.3 \%$ & $86.5 \%$ & $.24^{*}$ \\
Family & $54.5 \%$ & $93.5 \%$ & $.44^{* *}$ \\
\hline
\end{tabular}

${ }^{*} p<0.05 .{ }^{* *} p<0.01$.

collectively, predicted student school status on the SARS. Collectively, the seven protective factors were able to predict the overall SARS score $(R=.736, p=.00)$. Thus, the seven protective factors were able to account for $54.2 \%$ of the variance in the overall SARS score.

Individually, only Engaged $(r=-.694, p=.00)$ was found to be a strong predictor of the overall SARS score. The beta value for each of the seven protective factors from the multiple regression analysis is presented in Table 3.

\subsection{SPF-7 Ratings by Grade Level and Disability Classification}

The percentage of students whose needs exceeded universal intervention based on teacher ratings on the SPF-7 was calculated for grade level and for disability classification. Each of the seven protective factors was considered independently. The criteria used to determine whether a student's needs exceeded universal intervention was a teacher rating of $0=$ Never, or $1=$ Rarely on each of the seven protective factors. For teacher ratings on the SPF-7 at the grade level, the percentage of students whose needs exceeded universal intervention ranged from $6.4 \%$ to $25.9 \%$ (see Table 4). For teacher ratings on the SPF-7 by disability classification, the percentage of students whose needs exceeded universal intervention ranged from $18.6 \%$ to $58.3 \%$ (see Table 5).

\section{Discussion}

Universal screening is a critical foundation for school-based prevention and early intervention (Stoner, 2006). To date, advances in the development and use of universal screening methods for identifying children in need of academic interventions have outpaced the development of universal screening methods for the prevention and early identification of emotional and behavioral concerns. This study represents a first step in examining the use 
Table 3. Relative predictive value of the seven individual protective factors.

\begin{tabular}{cccc}
\hline Protective factors & Beta & $T$ & $p$ \\
\hline Engaged & -.548 & -3.838 & .000 \\
Connected & .222 & 1.490 & .140 \\
Empathy & -.186 & -1.551 & .125 \\
Pro-social peers & -.181 & -1.126 & .264 \\
Social skills & -.091 & -.578 & .565 \\
Family & -.043 & -.379 & .706 \\
Competence & .025 & .160 & .873 \\
\hline
\end{tabular}

Table 4. Percentage of students whose needs exceed universal intervention (Tier 1) Based on teacher ratings on the SPF-7 by grade level.

\begin{tabular}{|c|c|c|c|c|c|c|c|c|c|}
\hline \multirow[b]{2}{*}{$\underline{\text { Sample composition }}$} & \multicolumn{9}{|c|}{ Grade level } \\
\hline & $\mathrm{K}$ & 1 & 2 & 3 & 4 & 5 & 6 & 7 & 8 \\
\hline$N$ of classrooms & 10 & 14 & 23 & 21 & 13 & 11 & 9 & 5 & 6 \\
\hline$N$ of students & 172 & 149 & 277 & 253 & 206 & 162 & 159 & 95 & 120 \\
\hline \multicolumn{10}{|l|}{$\underline{\text { Protective factors }}$} \\
\hline Competence & $11.0 \%$ & $16.2 \%$ & $14.8 \%$ & $15.4 \%$ & $11.7 \%$ & $16.7 \%$ & $22.0 \%$ & $12.6 \%$ & $25.9 \%$ \\
\hline Social skills & $11.6 \%$ & $17.5 \%$ & $14.1 \%$ & $12.0 \%$ & $11.2 \%$ & $16.0 \%$ & $16.9 \%$ & $5.3 \%$ & $15.0 \%$ \\
\hline Empathy & $12.2 \%$ & $16.8 \%$ & $10.4 \%$ & $13.6 \%$ & $13.2 \%$ & $17.9 \%$ & $21.4 \%$ & $6.4 \%$ & $23.3 \%$ \\
\hline Peers & $9.3 \%$ & $20.8 \%$ & $13.7 \%$ & $13.1 \%$ & $11.6 \%$ & $18.5 \%$ & $17.1 \%$ & $6.4 \%$ & $14.2 \%$ \\
\hline Engaged & $11.1 \%$ & $14.4 \%$ & $14.9 \%$ & $17.5 \%$ & $15.1 \%$ & $19.7 \%$ & $23.9 \%$ & $20.0 \%$ & $20.8 \%$ \\
\hline Connected & $11.1 \%$ & $17.5 \%$ & $9.1 \%$ & $15.5 \%$ & $12.2 \%$ & $14.2 \%$ & $26.5 \%$ & $11.6 \%$ & $14.1 \%$ \\
\hline Family & $15.2 \%$ & $14.1 \%$ & $23.1 \%$ & $21.2 \%$ & $12.6 \%$ & $35.2 \%$ & $20.7 \%$ & $8.7 \%$ & $24.8 \%$ \\
\hline
\end{tabular}

Table 5. Percentage of students whose needs exceed universal intervention (Tier 1) Based on teacher ratings on the SPF-7 by disability classification.

\begin{tabular}{|c|c|c|c|c|c|c|}
\hline \multirow{2}{*}{ Protective factor } & \multicolumn{5}{|c|}{ Disability classification } & \multirow[b]{2}{*}{$\begin{array}{c}\text { Non-disabled } \\
(\mathrm{N}=1348)\end{array}$} \\
\hline & $\begin{array}{c}C D \\
(N=49)\end{array}$ & $\begin{array}{c}\text { ED } \\
(\mathrm{N}=12)\end{array}$ & $\begin{array}{c}\text { OHI } \\
(\mathrm{N}=13)\end{array}$ & $\begin{array}{c}\mathrm{SH} \\
(\mathrm{N}=78)\end{array}$ & $\begin{array}{c}\text { SLD } \\
(\mathrm{N}=70)\end{array}$ & \\
\hline Competence & $42.8 \%$ & $41.7 \%$ & $38.8 \%$ & $19.2 \%$ & $42.9 \%$ & $12.6 \%$ \\
\hline Social skills & $26.5 \%$ & $33.4 \%$ & $30.8 \%$ & $20.5 \%$ & $21.4 \%$ & $11.3 \%$ \\
\hline Empathy & $20.8 \%$ & $50.0 \%$ & $23.1 \%$ & $16.7 \%$ & $20.0 \%$ & $13.4 \%$ \\
\hline Pro-social peers & $28.5 \%$ & $33.4 \%$ & $25.0 \%$ & $20.8 \%$ & $32.8 \%$ & $11.4 \%$ \\
\hline Engaged & $43.8 \%$ & $58.3 \%$ & $30.8 \%$ & $21.8 \%$ & $30.0 \%$ & $14.4 \%$ \\
\hline Connected & $29.2 \%$ & $25.0 \%$ & $23.1 \%$ & $19.3 \%$ & $22.9 \%$ & $12.7 \%$ \\
\hline Family & $34.1 \%$ & $50.0 \%$ & $15.4 \%$ & $26.4 \%$ & $18.6 \%$ & $18.9 \%$ \\
\hline
\end{tabular}

Key to Disability Classification Codes CD: Cognitive Disability ED: Emotional Disturbance OHI: Other Health Impairment; SH: Speech or Language Impairment; SLD: Specific Learning Disability.

of a universal screening tool based on protective factors for identifying students in need of more intensive intervention. If further validated by future research, the SPF-7 may have potential as one piece of information that is easily administered, cost effective, and used proactively in the context of a response to intervention model to 
answer the question: which and how many students are potentially in need of additional support? There is no expectation that the SPF-7 should be used as a sole measure for sorting students for intervention or diagnosis.

The SPF-7 differs from other measures used for universal screening of emotional and behavioral concerns in that it focuses on protective factors rather than risk factors. Consequently, the SPF-7 is not vulnerable to the criticisms of anti-screening groups, such as the Church of Scientology and Concerned Women for America, who contend that the use of universal screening for mental health concerns usurp parental authority, enable pharmaceutical companies to market their products to school children, and promotes labeling children as mentally ill (Stoner, 2006).

As an initial step in examining the reliability and validity of the SPF-7, the findings suggest that the SPF-7 has modest potential a universal screening tool, although additional empirical investigations are needed. Teacher ratings on the SPF-7 yielded strong test-retest reliability coefficients for all seven protective factors across the 2-week and 18-week timeframes.

Inter-rater agreement coefficients were inadequate for all seven of the protective factors. This finding is consistent with previous research that suggests that the frequency of office disciplinary referrals is influenced by teachers' differing criteria, definitions of and tolerance for problem behavior, and reactivity to program implementation (Kern \& Manz, 2004).

The results of this study suggest that the SPF-7 demonstrated adequate criterion validity for the purpose of identifying behaviorally and emotionally at-risk students. The SPF-7 ratings were compared to overall SARS scores. When all seven protective factors were considered collectively, the SPF-7 accounted for $54.2 \%$ of the variance in SARS scores. When the seven protective factors that comprise the SPF-7 were considered individually, only Engaged was found to be a strong predictor of the overall SARS scores. This might suggest that of the seven protective factors on the SPF-7, a student's level of engagement and motivation to do well in school is the single best predictor of behavioral and emotional concerns, but the inclusion of additional protective factors increases the predictive value.

For a universal screening instrument to have practical value, the percentage of students identified by the measure should be equivalent to the number of students within the given population that would be expected to need additional support. One criticism of the Teenscreen is that too many students are being identified as at-risk for mental health concerns, overwhelming the resources available for intervention and consequently making school districts liable for meeting the needs of students identified (Anderson-Butcher, personal communication April 21, 2005). The teacher ratings on the SPF-7 identified $6.4 \%$ to $25.9 \%$ of students in the sample as having needs exceeding universal interventions. This finding is promising given that research suggests that universal interventions should meet the needs of $80 \%$ - 90\% of all students in any given student population, with $10 \%-20 \%$ of students requiring additional support (Sugai et al., 2002). The SPF-7 identified 18.6\% to 58.3\% of students with disabilities in the sample as having needs exceeding universal interventions. A higher percentage would be expected when considering students with disabilities, because these students have already been identified through the special education qualification process as needing extra interventions and supports beyond what is provided at the primary and secondary prevention levels.

\section{Future Directions and Implications}

The development, validation and use of protective factors in universal screening is in its infancy. Future research should replicate this initial study using a larger and more diverse student population. For example, recent research has investigated the use of the SPF-7 for developing micro-norms for language minority students (Morrison, Kobayashi, \& Bolognone, 2007). Another area for future research is to explore the utility of the SPF-7 as a screening instrument with students in secondary schools.

The SPF-7 has the potential to function as a cost effective, efficient screening tool at the elementary school level. Students who are identified by teacher ratings on the SPF-7 as behaviorally and emotionally at-risk could receive immediate support as opposed to waiting until the discipline records indicate there is a concern.

Information garnered from the SPF-7 could be used to identify the need for both selected (secondary prevention) and universal (primary prevention) interventions. Students who earn low ratings on a particular protective factor could be targeted for selected interventions. For example, several students within a particular classroom or grade level might all receive low ratings for the Social Skills factor. Further assessment would need to be conducted with the students to identify individual areas of need using a problem-solving approach. An intervention 
could be selected to target the problem area(s), and a plan developed as to monitor the student's progress throughout the intervention.

At the school-wide level, information from the SPF-7 could be used to inform the development and implementation of universal supports. For example, if low ratings on the connected factor were noted across a school, further assessment and problem solving would enable educators to understand the exact nature of the lack of connectedness. The result might be the development of a school-wide intervention to help students feel more connected to their teachers and to the school (e.g., a teacher-student mentoring program or a faculty-student volleyball game). Given its potential to identify students' needs proactively, the use of the SPF-7 could be the centerpiece on which a multi-tiered positive behavioral and academic intervention program is based.

\section{Acknowledgements}

The author wishes to acknowledge the contributions of Julie Thomas in identifying protective factors for inclusion in the SPF-7 and Kevin Jones for his guidance and feedback.

\section{References}

Achenbach, T. (1985). Assessment and Taxonomy Child and Adolescent Psychopathology. Beverly Hills, CA: Sage.

Alvord, M. K., \& Grados, J. (2005). Enhancing Resilience in Children: A Proactive Approach. Professional Psychology: Research and Practice, 36, 238-245. http://dx.doi.org/10.1037/0735-7028.36.3.238

Anderson, C. M., \& Kincaid, D. (2005). Applying Behavior Analysis to School Violence and Discipline Problems: SchoolWide Positive Behavior Support. Behavior Analyst, 28, 49-63.

Anastasi, A. (1988). Psychological Testing (6th ed.). New York: Macmillan.

Anderman, E. M., \& Maehr, M.L. (1994). Motivation and Schooling in the Middle Grades. Review of Educational Research, 64, 287-309. http://dx.doi.org/10.3102/00346543064002287

Appleton, J. J., Christenson, S. L., \& Furlong, M. J. (2008). Student Engagement with School: Critical Conceptual and Methodological Issues of the Construct. Psychology in the Schools, 45, 369-386. http://dx.doi.org/10.1002/pits.20303

Barnett, D. W., Daly III, E. J., Jones, K. M., \& Lentz Jr., F. (2004). Response to Intervention: Empirically Based Special Service Decisions from Single-Case Designs of Increasing and Decreasing Intensity. Journal of Special Education, 38, 66-79. http://dx.doi.org/10.1177/00224669040380020101

Bassarath, L. (2001). Conduct Disorder: A Biopsychosocial Review. Canadian Journal of Psychiatry, 46, 609-616.

Baumeister, R. F., \& Leary, M. R. (1995). The Need to Belong: Desire for Interpersonal Attachments as a Fundamental Motivation. Psychological Bulletin, 117, 497-529. http://dx.doi.org/10.1037/0033-2909.117.3.497

Birch, S., \& Ladd, G. W. (1997). The Teacher-Child Relationship and Children's Early School Adjustment. Journal of School Psychology, 35, 61-79. http://dx.doi.org/10.1016/S0022-4405(96)00029-5

Bonny, A. E., Britto, M. T., Klostermann, B. K., Hornung, R. W., \& Slap, G. B. (2000). School Disconnectedness Identifying Adolescents at Risk. Pediatrics, 106, 1017-1021. http://dx.doi.org/10.1542/peds.106.5.1017

Booth, A., \& Dunn, J. F. (1996). Family-School Links: How Do They Affect Education Outcomes. Mahwah, NJ: Erlbaum.

Brown, B. B., \& Huang, G. H. (1995). Examining Parenting Practices in Different Peer Contexts: Implications for Adolescent Trajectories. In L. J. Crockett, \& A. C. Crouter (Eds.), Pathways through Adolescence: Relation to Social Contexts (pp. 151-174). Mahwah, NJ: Erlbaum.

Brown-Chidsey, R., \& Steeg, M. (2005). Response to Intervention: Principles and Strategies for Effective Practice. New York: Guilford.

Cairns, R. B., Cairns, B. D., Neckerman, H. J., Gest, S. D., \& Gariepy, J. L. (1988). Peer Networks and Aggressive Behavior: Peer Support or Peer Rejection? Developmental Psychology, 24, 815-823. http://dx.doi.org/10.1037/0012-1649.24.6.815

Canter, A. S., Lau, M. Y., \& House, A. (2002). Best Practices in Developing Local Norms in Behavioral Assessment. In A. Thomas, \& J. Grimes (Eds.), Best Practices in School Psychology, Fourth Edition (pp. 1099-1114). Bethesda, MD: National Association of School Psychologists.

Caprara, G. V., Barbaranelli, C., Pastorelli, C., Bandura, A., \& Zimbardo, P. G. (2000). Prosocial Foundations of Children’s Academic Achievement. Psychological Science, 11, 302-306. http://dx.doi.org/10.1111/1467-9280.00260

Catalano, R. F., \& Hawkins, J. D. (1996). The Social Development Model: A Theory of Antisocial Behavior. In J. D. Hawkins (Ed.), Delinquency and Crime: Current Theories (pp. 149-197). New York: Cambridge University Press.

Christenson, S. L., Sinclair, M. F., Lehr, C. A., \& Godber, Y. (2001). Promoting Successful School Completion: Critical 
Conceptual and Methodological Guidelines. School Psychology Quarterly, 16, 468-484. http://dx.doi.org/10.1521/scpq.16.4.468.19898

Clark, R. M. (1993). Homework-Focused Parenting Practices That Positively Affect Student Achievement. In N. F. Chavkin (Ed.), Families and Schools in a Pluralistic Society. Albany, NY: State University of New York Press.

Coie, J. D., \& Jacobs, M. R. (1993). The Role of Social Context in the Prevention of Conduct Disorder. Development and Psychopathology, 5, 263-275. http://dx.doi.org/10.1017/S0954579400004387

Connell, J. P., Halpern-Felsher, B. L., Clifford, E., Crichlow, W., \& Usinger, P. (1995). Hanging in There: Behavioral, Psychological, and Contextual Factors Affecting Whether African American Adolescents Stay in High School. Journal of Adolescent Research, 10, 41-63. http://dx.doi.org/10.1177/0743554895101004

Criss, M. M., Pettit, G. S., Bates, J. E., Dodge, K. A., \& Lapp, A. L. (2002). Family Adversity, Positive Peer Relationships, and Children's Externalizing Behavior: A Longitudinal Perspective on Risk and Resilience. Child Development, 73, 1220-1237. http://dx.doi.org/10.1111/1467-8624.00468

de Wied, M., Goudena, P. P., \& Matthys, W. (2005). Empathy in Boys with Disruptive Behavior Disorders. Journal of Child Psychology and Psychiatry, 46, 867-880. http://dx.doi.org/10.1111/j.1469-7610.2004.00389.x

DiPerna, J., \& Elliott, S. N. (2000). Academic Competence Evaluation Scales. San Antonio, TX: Harcourt Assessment.

DiPerna, J. C., Volpe, R. J., \& Elliott, S. N. (2002). A Model of Academic Enablers and Elementary Reading/Language Arts Achievement. School Psychology Review, 31, 298-312.

Dishion, T. J., Andrews, D. W., \& Crosby, L. (1995). Antisocial Boys and Their Friends in Early Adolescence: Relationship Characteristics, Quality, and Interactional Process. Child Development, 66, 139-151. http://dx.doi.org/10.2307/1131196

Dishion, T. J., Patterson, G. R., Stoolmiller, M., \& Skinner, M. L. (1991). Family, School, and Behavioral Antecedents to Early Adolescents Involvement with Antisocial Peers. Developmental Psychology, 27, 172-180.

http://dx.doi.org/10.1037/0012-1649.27.1.172

Doll, B., \& Hess, R. S. (2001). Through a New Lens: Contemporary Psychological Perspectives on School Completion and Dropping Out of High School. School Psychology Quarterly, 16, 351-356. http://dx.doi.org/10.1521/scpq.16.4.351.19895

Doll, B., \& Lyon, M. A. (1998). Risk and Resilience: Implications for the Delivery of Educational and Mental Health Services in Schools. School Psychology Review, 27, 348-363.

Drummond, T. (1993). The Student Risk Screening Scale (SRSS). Grants Pass, OR: Josephine County Mental Health Program.

Dunn, C. W., \& Tucker, M. (1993). Black Children’s Adaptive Functioning and Maladaptive Behavior Associated with Quality of Family Support. Journal of Multicultural Counseling and Development, 21, 79-87. http://dx.doi.org/10.1002/j.2161-1912.1993.tb00586.x

Eccles, J. S., Wigfield, A., Midgley, C., Reuman, D., MacIver, D., \& Feldlaufer, H. (1993). Negative Effects of Traditional Middle Schools on Students’ Motivation. The Elementary School Journal, 93, 553-574. http://dx.doi.org/10.1086/461740

Eisenberg, N., Fabes, R. A., Shepard, S. A., Murphy, B. C., Guthrie, I. K., Jones, S., Friedman, J., Poulin, R., \& Maszk, P. (1997). Contemporaneous and Longitudinal Prediction of Children's Social Functioning from Regulation and Emotionality. Child Development, 68, 642-664. http://dx.doi.org/10.2307/1132116

Elliott, S. N., Huai, N., \& Roach, A. T. (2007). Universal and Early Screening for Educational Difficulties: Current and Future Approaches. Journal of School Psychology, 45, 137-161. http://dx.doi.org/10.1016/j.jsp.2006.11.002

Epstein, J. L. (1983). Longitudinal Effects of Family-School-Person Interactions on Student Outcomes. In A. Kerckhoff (Ed.), Research in Sociology of Education and Socialization (Vol. 4, pp. 101-128). Greenwich, CT: JAI.

Feil, E. G., Severson, H. H., \& Walker, H. M. (2002). Early Screening and Intervention to Prevent the Development of Aggressive, Destructive Behavior Patterns among At-Risk Children. In M. R. Shinn, H. M. Walker, \& G. Stoner (Eds.), Interventions for Achievement and Behavior Problems II: Preventive and Remedial Approaches. Bethesda, MD: The National Association of School Psychologists.

Finn, J. D. (1989). Withdrawing from School. Review of Educational Research, 59, 117-142. http://dx.doi.org/10.3102/00346543059002117

Finn, J. D. (1993). School Engagement and Students at Risk. Washington DC: National Center for Education Statistics.

Finn, J. D., \& Rock, D. A. (1997). Academic Success among Students at Risk for School Failure. Journal of Applied Psychology, 82, 221-234. http://dx.doi.org/10.1037/0021-9010.82.2.221

Fredericks, J. A., Blumenfeld, P. C., \& Paris, A. H. (2004). School Engagement: Potential of the Concept, State of the Evidence. Review of Educational Research, 74, 59-109. http://dx.doi.org/10.3102/00346543074001059

Furlong, M. J., Whipple, A. D., St. Jean, G., Simental, J., Soliz, A., \& Punthuna, S. (2003). Multiple Contexts of School En- 
gagement: Moving toward a Unifying Framework for Educational Research and Practice. California School Psychologist, 8, 99-114. http://dx.doi.org/10.1007/BF03340899

Garnefski, N., \& Diekstra, W. (1996). Perceived Social Support from Family, School, and Peers: Relationship with Emotional and Behavioral Problems among Adolescents. Journal of the American Academy of Child \& Adolescent Psychiatry, 35, 1657-1664. http://dx.doi.org/10.1097/00004583-199612000-00018

Gresham, F. M. (2002). Best Practices in Social Skills Training. In A. Thomas, \& J. Grimes (Eds.), Best Practices in School Psychology IV (pp. 1029-1040). Bethesda, MD: National Association of School Psychologists.

Gresham, F. M. (2004). Current Status and Future Directions of School-Based Behavioral Interventions. School Psychology Review, 33, 326-343.

Gresham, F. M. (2005). Response to Intervention: An Alternative Means of Identifying Students as Emotionally Disturbed. Education and Treatment of Children, 28, 328-344.

Habedank, L. (1995). Best Practices in Developing Local Norms for Problem Solving in the Schools. In A. Thomas, \& J. Grimes (Eds.), Best Practices in School Psychology (3rd ed., pp. 701-715). Washington DC: National Association of School Psychologists.

Henricsson, L., \& Rydell, A. (2004). Elementary School Children with Behavior Problems: Teacher-Child Relations and Self-Perception. A Prospective Study. Merrill-Palmer Quarterly, 50, 111-138. http://dx.doi.org/10.1353/mpq.2004.0012

Hinshaw, S. (1987). On the Distinction between Attention Deficit/Hyperactivity and Conduct Problems/Aggression in Child Psychopathology. Psychological Bulletin, 101, 443-463. http://dx.doi.org/10.1037/0033-2909.101.3.443

Hinshaw, S. (1992). Externalizing Behavior Problems and Academic Underachievement in Childhood and Adolescence: Causal Relationships and Underlying Mechanisms. Psychological Bulletin, 111, 127-155. http://dx.doi.org/10.1037/0033-2909.111.1.127

Horner, R. H., Sugai, G., Todd, A. W., \& Lewis-Palmer, T. (2005). School-Wide Positive Behavior Support. In L. Bambara, \& L. Kern (Eds.), Individualized Supports for Students with Problem Behaviors: Designing Positive Behavior Plans (pp. 359-390). New York: Guilford Press.

Ikeda, M. J., Neessen, E., \& Witt, J. C. (2008). Best Practices in Universal Screening. In A. Thomas, \& J. Grimes (Eds.), Best Practices in School Psychology (5th ed., pp. 103-114). Bethesda, MD: National Association of School Psychologists.

Irvin, L. K., Horner, R. H., Ingram, K., Todd, A. W., Sugai, G., Sampson, N. K., et al. (2006). Using Office Discipline Referral Data for Decision Making about Student Behavior in Elementary and Middle Schools: An Empirical Evaluation of Validity. Journal of Positive Behavior Interventions, 8, 10-23. http://dx.doi.org/10.1177/10983007060080010301

Irvin, L. K., Tobin, T. J., Sprague, J. R., Sugai, G., \& Vincent, C. G. (2004). Validity of Office Discipline Referral Measures as Indices of School-Wide Behavioral Status and Effects of School-Wide Behavioral Interventions. Journal of Positive Behavioral Interventions, 6, 131-147. http://dx.doi.org/10.1177/10983007040060030201

Jimerson, S. R., Campos, E., \& Greif, J. L. (2003). Toward an Understanding of Definitions and Measures of School Engagement and Related Terms. California School Psychologist, 8, 7-27. http://dx.doi.org/10.1007/BF03340893

Kamphaus, R. W., \& Reynolds, C. R. (2007). BASC-2 Behavioral and Emotional Screening System. Minneapolis, MN: Pearson.

Karcher, M. J. (2002). The Cycle of Violence and Disconnection among Rural Middle School Students: Teacher Disconnection as a Consequence of Violence. Journal of School Violence, 1, 35-51.

http://dx.doi.org/10.1300/J202v01n01_03

Karcher, M. J., Davis, C., \& Powell, B. (2002). The Effects of Developmental Mentoring on Connectedness and Academic Achievement. School Community Journal, 12, 35-50.

Kavale, K. A., \& Forness, S. R. (1998). Covariance in Learning Disability and Behavior Disorder: An Examination of Classification and Placement Issues. In T. E. Scruggs, \& M. A. Mastropieri (Eds.), Advances in Learning and Behavioral Disabilities (pp. 1-42). Greenwich, CT: JAI Press.

Kazdin, A. (1987). Treatment of Antisocial Behavior in Children: Current Status and Future Directions. Psychological Bulletin, 102, 187-203. http://dx.doi.org/10.1037/0033-2909.102.2.187

Kazdin, A. E., Kraemer, H. C., Kessler, R. C., \& Kupfer, D. J. (1997). Contributions of Risk-Factor Research to Developmental Psychopathology. Clinical Psychology Review, 17, 375-406. http://dx.doi.org/10.1016/S0272-7358(97)00012-3

Kern, L., \& Manz, P. (2004). A Look at Current Validity Issues of School-Wide Behavior Support. Behavioral Disorders, 30, 47-59.

Kilgus, S. P., Chafouleas, S. M., \&Riley-Tillman, T. C. (2013). Development and Initial Validation of the Social and Aca- 
demic Behavior Risk Screener for Elementary Grades. School Psychology Quarterly, 28, 210-226. http://dx.doi.org/10.1037/spq0000024

Kochenderfer, B. J., \& Ladd, G. W. (1996). Peer Vicitimization: Cause or Consequence of School Maladjustment? Child Development, 67, 1305-1317. http://dx.doi.org/10.2307/1131701

Kuperminc, G. P., Blatt, S. J., \& Leadbeater, B. J. (1997). Relatedness, Self-Definition, and Early Adolescent Adjustment. Cognitive Therapy and Research, 21, 301-320. http://dx.doi.org/10.1023/A:1021826500037

Kupersmidt, J. B., \& Coie, J. D. (1990). Preadolescent Peer Status, Aggression, and School Adjustment as Predictors of Externalizing Problems in Adolescence. Child Development, 61, 1350-1362. http://dx.doi.org/10.2307/1130747

Kupersmidt, J., Coie, J., \& Dodge, K., (1990). The Role of Peer Relationships in the Development of Disorder. In S. Asher, \& J. Coie (Eds.), Peer Rejection in Childhood (pp. 274-308). New York: Cambridge University Press.

Ladd, G. W., Kochenderfer, B. J., \& Coleman, C. C. (1997). Classroom Peer Acceptance, Friendship, and Victimization: Distinct Relational Systems That Contribute Uniquely to Children's School Adjustment? Child Development, 68, 1181-1197. http://dx.doi.org/10.2307/1132300

Lane, K. L., Kalberg, J. R., Parks, R. J., \& Carter, E. W. (2008). Student Risk Screening Scale: Initial Evidence for Score Reliability and Validity at the High School Level. Journal of Emotional and Behavioral Disorders, 16, 178-190. http://dx.doi.org/10.1177/1063426608314218

Lane, K. L., Menzies, H. M., Oakes, W. P., Kalberg, J. R. (2012). Systematic Screenings of Behavior to Support Instruction: From Preschool to High School. New York: Guilford Press.

Majoribanks, K. (1987). Ability and Attitude Correlates of ACADEMIC achievement: Family Group Differences. Journal of Educational Psychology, 79, 171-178. http://dx.doi.org/10.1037/0022-0663.79.2.171

Masten, A. S., \& Coatsworth, J. D. (1998). The Development of Competence in Favorable and Unfavorable Environments: Lessons from Research on Successful Children. American Psychologist, 53, 205-220. http://dx.doi.org/10.1037/0003-066X.53.2.205

Malecki, C. K., \& Elliott, S. N. (2002). Children's Social Behaviors as Predictors of Academic Achievement: A Longitudinal Analysis. School Psychology Quarterly, 17, 1-23. http://dx.doi.org/10.1521/scpq.17.1.1.19902

Marston, D. (2005). Tiers of Intervention in Responsiveness to Intervention: Prevention Outcomes and Learning Disabilities Identification Patterns. Journal of Learning Disabilities, 38, 539-544. http://dx.doi.org/10.1177/00222194050380061001

Morano, C. D., Cisler, R. A., \& Lemerond, J. (1993). Risk Factors for Adolescent Suicidal Behavior: Loss, Insufficient Familial Support, and Hopelessness. Adolescence, 28, 851-865.

Morrison, G. M., Robertson, L., Laurie, B., \& Kelly, J. (2002). Protective Factors Related to Antisocial Behavior Trajectories. Journal of Clinical Psychology, 58, 277-290. http://dx.doi.org/10.1002/jclp.10022

Morrison, J. Q., Kobayashi, M., \& Bolognone, J. (2007). Use of Protective Factors to Develop Behavioral Norms for English Language Learners. Unpublished manuscript, Dayton, OH: University of Dayton.

Mounts, N. S., \& Steinberg, L. (1995). An Ecological Analysis of Peer Influence on Adolescent Grade Point Average and Drug Use. Developmental Psychology, 31, 915-922. http://dx.doi.org/10.1037/0012-1649.31.6.915

Murray, C., \& Greenberg, T. (2000). Children's Relationship with Teachers and Bonds with School. An Investigation of Patterns and Correlates in Middle Childhood. Journal of School Psychology, 38, 423-445.

http://dx.doi.org/10.1016/S0022-4405(00)00034-0

National Research Council \& Institute of Medicine (2004). Engaging Schools: Fostering High School Students' Motivation to Learn. Washington DC: The National Academies Press.

Osher, D., Dwyer, K., \& Jimerson, S. R. (2006). Safe, Supportive, and Effective Schools: Promoting School Success to Reduce School Violence. In S. R. Jimerson, \& M. J. Furlong (Eds.), The Handbook of School Violence and School Safety: From Research to Practice (pp. 51-71). Mahwah, NJ: Lawrence Erlbaum.

Parker, J., \& Asher, S. (1987). Peer Relations and Later Personal Adjustment: Are Low-Accepted Children At-Risk? Psychological Bulletin, 102, 357-389. http://dx.doi.org/10.1037/0033-2909.102.3.357

Patterson, G. R., DeBaryshe, B. D., \& Ramsey, E. (1989). A Developmental Perspective on Antisocial Behavior. American Psychologist, 44, 329-335. http://dx.doi.org/10.1037/0003-066X.44.2.329

Piko, B. F., Fitzpatrick, K. M., \& Wright, D. R. (2005). A Risk and Protective Factors Framework for Understanding Youth's Externalizing Problem Behavior in Two Different Cultural Settings. European Child \& Adolescent Psychiatry, 14, 95-103. http://dx.doi.org/10.1007/s00787-005-0437-z

Pianta, R. C., Steinberg, M., \& Rollins, K. (1995). The First Two Years of School: Teacher-Child Relationships and Deflections in Children's Classroom Adjustment. Development and Psychopathology, 7, 295-312. http://dx.doi.org/10.1017/S0954579400006519

Putnam, R. F., Luiselli, J. K., Handler, M. W., \& Jefferson, G. L. (2003). Evaluating Student Discipline Practices in a Public 
School through Behavioral Assessment of Office Referrals. Behavior Modification, 27, 505-523. http://dx.doi.org/10.1177/0145445503255569

Reschly, A., \& Christenson, S. L. (2006a). Promoting Successful School Completion. In G. Bear, \& K. Minke (Eds.), Children's Needs, III: Development, Prevention, and Intervention (pp. 103-113). Bethesda, MD: National Association of School Psychologists.

Reschly, A., \& Christenson, S. L. (2006b). Research Leading to a Predictive Model of Dropout and Completion among Students with Mild Disabilities and the Role of Student Engagement. Remedial and Special Education, 27, $276-292$. http://dx.doi.org/10.1177/07419325060270050301

Reynolds, A. J., \& Wahlberg, H. J. (1991). A Structural Model of Science Achievement. Journal of Educational Psychology, 83, 97-107. http://dx.doi.org/10.1037/0022-0663.83.1.97

Roberts, W., \& Strayer, J. (1996). Empathy, Emotional Expressiveness, and Prosocial Behavior. Child Development, 67, 449-470. http://dx.doi.org/10.2307/1131826

Ryan, B. A., Adams, G. R., Gullotta, T. P., Weissberg, R. P., \& Hampton, R. L. (1995). The Family-School Connection: Theory, Research and Practice. Thousand Oaks, CA: Sage.

Scott-Jones, D. (1995). Parent-Child Interactions and School Achievement. In B. A. Ryan, G. R. Adams, T. P. Gullotta, R. P. Weissberg, \& R. L. Hampton (Eds.), The Family-School Connection: Theory, Research and Practice (Vol. 2, pp. 75-107). Thousand Oaks, CA: Sage.

Severson, H. H., Walker, H. M., Hope-Doolittle, J., Kratochwill, T. R., \& Gresham, F. M. (2007). Proactive, Early Screening to Detect Behaviorally At-Risk Students: Issues, Approaches, Emerging Innovations, and Professional Practices. Journal of School Psychology, 45, 193-223. http://dx.doi.org/10.1016/j.jsp.2006.11.003

Smokowski, P. R., Mann, E. A., Reynolds, A. J., \& Fraser, M. W. (2004). Childhood Risk and Protective Factors and Late Adolescent Adjustment in Inner City Minority Youth. Children and Youth Services Review, 26, 63-91. http://dx.doi.org/10.1016/j.childyouth.2003.11.003

Spoth, R., Yoo, S., Kahn, J. H., \& Redmond, C. (1996). A Model of the Effects of Protective Parent and Peer Factors on Young Adolescent Alcohol Refusal Skills. Journal of Primary Prevention, 16, 373-394. http://dx.doi.org/10.1007/BF02411742

Sprague, J. R., \& Horner, R. H. (2006). School Wide Positive Behavioral Supports. In S. R. Jimerson, \& M. J. Furlong (Eds.), The Handbook of School Violence and School Safety: From Research to Practice. Mahwah, NJ: Lawrence Erlbaum.

Steinberg, L. (1996). Beyond the Classroom: Why School Reform Has Failed and What Parents Need to Do. New York: Simon \& Schuster.

Steinberg, L., Lamborn, S. D., Dornbusch, S. M., \& Darling, N. (1992). Impact of Parenting Practices on Adolescent Achievement: Authoritative Parenting, School Involvement, and Encouragement to Succeed. Child Development, 63, 1266-1281. http://dx.doi.org/10.2307/1131532

Steinhausen, H., \& Metzke, W. (2001). Risk, Compensatory, Vulnerability, and Protective Factors Influencing Mental Health in Adolescence. Journal of Youth and Adolescence, 30, 259-280. http://dx.doi.org/10.1023/A:1010471210790

Stevenson, H. W., Chen, C., \& Lee, S. Y. (1993). Mathematics Achievement of Chinese, Japanese, and American Children: Ten Years Later. Science, 259, 53-58. http://dx.doi.org/10.1126/science.8418494

Stoner, G. (2006). School Psychology and Screening for Problems. The School Psychologist, 60, 104-105, 132.

Strayer, J., \& Roberts, W. (2004). Empathy and Observed Anger and Aggression in Five-Year-Olds. Social Development, 13, 1-13. http://dx.doi.org/10.1111/j.1467-9507.2004.00254.x

Sugai, G., \& Horner, R. H. (2002). Introduction to the Special Series on Positive Behavior Support in Schools. Journal of Emotional and Behavioral Disorders, 10, 130-135. http://dx.doi.org/10.1177/10634266020100030101

Sugai, G., Sprague, J. R., Horner, R. H., \& Walker, H. M. (Eds.). (2001). Preventing School Violence: The Use of Office Discipline Referrals to Assess and Monitor School-Wide Discipline Intervention (reprinted chapter). Austin, TX: Pro-Ed, Inc.

Todis, B., Severson, H. H., \& Walker, H. M. (1990). The Critical Events Scale: Behavioral Profiles of Students with Externalizing and Internalizing Behavior Disorders. Behavioral Disorders, 15, 75-86.

Walker, H. M., Block-Pedego, A., Todis, B., \& Severson, H. (1991). School Archival Records Search. Longmont, CO: Sopris West.

Walker, H. M., Colvin, G., \& Ramsey, E. (1995). Antisocial Behavior in School: Strategies and Best Practices. Pacific Grove, CA: Brooks/Cole.

Walker, H. M., \& Shinn, M. A. (2002). Structuring School-Based Interventions to Achieve Integrated Primary, Secondary, and Tertiary Prevention Goals for Safe and Effective Schools. In M. Shinn, H. Walker, \& G. Stoner (Eds.), Interventions for Academic and Behavior Problems II (pp. 1-26). Bethesda, MD: National Association of School Psychologists. 


\section{Appendix}

Student Protective Factors Screening Scale (SPF-7)

Directions: Please rate each student in your class using the following scale: $0=$ Never, $1=$ Rarely, 2 = Occasionally, 3 = Frequently.

\begin{tabular}{|c|c|c|c|c|c|c|c|}
\hline $\begin{array}{c}\text { Student } \\
\text { name }\end{array}$ & $\begin{array}{l}\text { Demonstrates } \\
\text { competence, is } \\
\text { optimistic, and } \\
\text { has a sense } \\
\text { of purpose }\end{array}$ & $\begin{array}{l}\text { Has effective } \\
\text { social skills } \\
\text { (relates well to } \\
\text { others, has good } \\
\text { friendship skills) }\end{array}$ & $\begin{array}{l}\text { Shows respect } \\
\text { and concern } \\
\text { for others } \\
\text { (empathy) }\end{array}$ & $\begin{array}{l}\text { Identifies with } \\
\text { pro-social } \\
\text { peer group(s) }\end{array}$ & $\begin{array}{l}\text { Engaged and } \\
\text { motivated to } \\
\text { do well } \\
\text { in school }\end{array}$ & $\begin{array}{l}\text { Connected with } \\
\text { teachers and } \\
\text { school }\end{array}$ & $\begin{array}{c}\text { Family is supportive } \\
\text { and invested } \\
\text { in student's } \\
\text { school success }\end{array}$ \\
\hline
\end{tabular}

